\title{
Between Dialogue and Denunciation: The World Council of Churches, Religious Freedom, and Human Rights during the Cold War
}

\author{
Bastiaan Bouwman (D) \\ Cluster of Excellence 'Contestations of the Liberal Script (SCRIPTS)', Freie Universität Berlin, Boltzmannstraße 20, \\ 14195 Berlin, Germany \\ bastiaanbouwman@gmail.com
}

While the historiography on the religious Cold War has tended to focus on Christian anticommunism, the World Council of Churches (WCC) sought to transcend the Cold War while simultaneously advancing religious freedom in the Soviet Union. This article connects the WCC's ecclesiastical diplomacy to the wider story of human rights, from which religion has too often been excluded. The WCC's quest for Christian fellowship led it to integrate the Russian Orthodox Church into its membership, but this commitment generated tensions with the rise of Soviet dissidence. Moreover, the WCC's turn towards the left and the Third World contrasted with newly ascendant voices for human rights in the 1970s: Amnesty International's depoliticised liberalism, evangelical anticommunism, and the Vatican under John Paul II. Thus, the WCC, an early and prominent transnational voice for human rights, ran afoul of shifts in both the Cold War and the politics of protest.

'Though deprived of all material strength, it [the church] is always victorious in sacrifice.' ${ }^{1}$ Aleksandr Solzhenitsyn, 1972

'[I]nfrequently do those in the West who would like to help take the trouble to find out what it is, in fact, which does help. ${ }^{2}$ - Dwain C. Epps (in notes for a speech by WCC General Secretary Philip Potter), 1976

\section{Introduction}

As the wartime alliance between the United States, Great Britain, and the Soviet Union deteriorated in the late 1940s and tensions escalated into the Cold War, Europe was divided not only militarily but also ideologically. Religion played an important role in this struggle 'for the soul of mankind', not least through the issue of religious freedom, which was sharply curtailed by the socialist regimes of the Eastern bloc. ${ }^{4}$ The question of religious freedom became part of the Cold War contest over the

\footnotetext{
1 Quoted in Jane Ellis, The Russian Orthodox Church: A Contemporary History (London and Sydney: Croom Helm, 1986), 304.

2 Epps to Potter, 15 Apr. 1976, Archives of the World Council of Churches, Geneva (hereafter WCCA) CCIA 428.15.3.4, 3.

3 Melvyn P. Leffler, For the Soul of Mankind: The United States, the Soviet Union, and the Cold War (New York: Hill and Wang, 2007).

4 On church-state relations in the Soviet Union, see Tatiana A. Chumachenko, Church and State in Soviet Russia: Russian Orthodoxy from World War II to the Khrushchev Years, 1st edn trans., Edward E. Roslof (Abingdon: Routledge, 2015;

(C) The Author(s), 2021. Published by Cambridge University Press. This is an Open Access article, distributed under the terms of the Creative Commons Attribution-NonCommercial-NoDerivatives licence (http://creativecommons.org/licenses/by-nc-nd/4.0/), which permits non-commercial re-use, distribution, and reproduction in any medium, provided the original work is unaltered and is properly cited. The written permission of Cambridge University Press must be obtained for commercial re-use or in order to create a derivative work.
} 
meaning of human rights, with adherence to one interpretation or another serving as 'powerful emblems of success on the ideological battleground'. ${ }^{5}$ The onset of the Cold War coincided with the promulgation of the Universal Declaration of Human Rights in December 1948, which included as its Article 18 an expansive conception of religious freedom - the result of successful lobbying by religious groups, which challenged the prevalent and more limited concept of freedom of worship as insufficient to safeguard religion's place in society. ${ }^{6}$ Several decades on, the question of human rights, including religious freedom, acquired newfound salience through its inclusion in the Helsinki Final Act (1975). The Soviet Union's rhetorical commitment to this document and its ensuing implementation process would galvanise renewed domestic and international pressure to increase political and religious freedom in the Eastern bloc. ${ }^{7}$

This resurgence of human rights as part of the Cold War was connected to a more general ascent of human rights to the top of the international agenda during the 1970s, in what has been termed its 'breakthrough' moment. ${ }^{8}$ In this decade, both the Cold War and the concept of human rights underwent transformations: increased contacts between East and West meshed with the rise of grassroots human rights organisations like Amnesty International. Amnesty famously sought to transcend the Cold War by championing a conception of human rights that was narrow in scope, focused on particular individual civil and political rights while eschewing attention to the broader political context at play, and which depended on a fast-moving politics of information, publicity, and humanitarian compassion. ${ }^{9}$ Other nongovernmental organisations, though, like the Helsinki Watch committees founded after 1975, adopted a politics of human rights that appealed to universality at the same time as it aligned itself with a mounting critique of détente: international peace should not come at the price of condoning domestic repression. Against this background, Soviet dissidents like the writer Aleksandr Solzhenitsyn, who was outspoken not only on the repression of political but also religious dissidence, became icons of the new politics of human rights. To the extent that these developments influenced Gorbachev's policy of liberalisation, human rights, including the question of religious freedom, contributed to the end of the Cold War and the downfall of communism. ${ }^{10}$

One of the leading voices for human rights, and especially religious freedom, from the 1940s onward, was the World Council of Churches (WCC). Affiliates of the WCC were responsible for crafting the above-mentioned Article 18, which became a cornerstone of advocacy of religious freedom across the world. At the same time, though, the WCC pursued a policy of engagement with Soviet churches: while it was initially rebuffed, by 1961 the WCC had integrated the Russian Orthodox

2002); John Anderson, Religion, State and Politics in the Soviet Union and Successor States, 1953-1993 (Cambridge: Cambridge University Press, 1994).

5 Rosemary Foot, 'The Cold War and Human Rights', in Melvyn P. Leffler and Odd Arne Westad, eds., The Cambridge History of the Cold War, vol. 3 (Cambridge: Cambridge University Press, 2010), 445. Cf. Barbara Keys and Roland Burke, 'Human Rights', in Richard H. Immerman and Petra Goedde, eds., The Oxford Handbook of the Cold War (Oxford: Oxford University Press, 2013), 486-502.

6 Linde Lindkvist, Religious Freedom and the Universal Declaration of Human Rights (Cambridge: Cambridge University Press, 2017), 107. Article 18 read: 'Everyone has the right to freedom of thought, conscience and religion; this right includes freedom to change his religion or belief, and freedom, either alone or in community with others and in public or private, to manifest his religion or belief in teaching, practice, worship and observance.'

7 Sarah B. Snyder, Human Rights Activism and the End of the Cold War: A Transnational History of the Helsinki Network (Cambridge: Cambridge University Press, 2011).

8 Jan Eckel and Samuel Moyn, eds., The Breakthrough: Human Rights in the 1970s (Philadelphia: University of Pennsylvania Press, 2014).

9 Samuel Moyn, The Last Utopia: Human Rights in History (Cambridge, MA: The Belknap Press of Harvard University Press, 2010); Jan Eckel, 'The International League for the Rights of Man: Amnesty International, and the Changing Fate of Human Rights Activism from the 1940s through the 1970', Humanity, 4, 2 (2013), 183-214.

10 On Soviet dissidents' relationship to human rights, see Benjamin Nathans, 'The Disenchantment of Socialism: Soviet Dissidents, Human Rights, and the New Global Morality', in Eckel and Moyn, The Breakthrough, 33-48. 
Church - by far the biggest and historically most significant confession in the Soviet Union ${ }^{11}$ - into its membership, while continuing to raise the issue of religious freedom in statements and exchanges with Soviet churchmen and authorities. Paradoxically, however, during the 1970s rise of human rights, in which Soviet dissidence played such a central role, the WCC's approach to religious liberty in the Eastern bloc came under heavy criticism. This turn of events was all the more striking given that the WCC was at the time actively positioning itself as a distinctively global voice for human rights, most notably through its opposition to dictatorships in Latin America. How did one of the earliest and most significant proponents of religious freedom in the Soviet Union wind up being cast by critics as failing to address the suppression of religious dissent?

In answering this question, this article is positioned at the intersection of the historiographies on the 'religious Cold War' and the postwar history of human rights, contributing to both by highlighting the ways in which these subjects were entangled. Religion has often been neglected in both areas of scholarship, but recent work has begun to rectify this. Scholarship on the religious Cold War has tended, though, to focus on anticommunism, especially on the part of the United States and the Vatican, which cast the Soviet Union's militant atheism as a threat to the Christian West. ${ }^{12}$ This article builds on the work of Dianne Kirby, Andrew Preston, Katharina Kunter, and others, who have recently challenged this Manichean framework by highlighting actors who sought to avoid taking sides in the Cold War and instead pursued connections across the East-West divide, as well as paying attention to the complexity of the dynamics of religion in the Soviet Union. ${ }^{13}$ Meanwhile, the article carries forward the agenda developed by scholars like Samuel Moyn, Gene Zubovich, and Pamela Slotte, who have drawn attention to the important role played by Christian actors in the twentieth-century history of human rights, showing how theologically-informed visions of politics underlay even secularised conceptions of human rights. ${ }^{14}$ Scholars working on the WCC in particular, such as Justin Reynolds, Udi Greenberg, and Christian Albers, have noted its desire to chart a 'third way' between the blocs, and have most recently expanded the frame in which its human rights engagement is considered: the WCC operated not only in relation to an East-West axis but also one running from

11 This article focuses on the Russian Orthodox Church and thus leaves out other major groups such as Baptists, Jews, Old Believers, Roman Catholics, Lutherans, Jehova's Witnesses, and of course the second-largest religious group in the Soviet Union, Muslims.

12 For a recent survey see Dianne Kirby, 'The Religious Cold War', in Immerman and Goedde, The Oxford Handbook of the Cold War, 540-64; see also Andrew Preston, Sword of the Spirit, Shield of Faith: Religion in American War and Diplomacy (New York: Alfred A. Knopf, 2012), part 7; Dianne Kirby, ed., Religion and the Cold War (Basingstoke: Palgrave, 2003); Philip Muehlenbeck, ed., Religion and the Cold War: A Global Perspective (Nashville: Vanderbilt University Press, 2012).

13 Kirby, 'The Religious Cold War'; Andrew Preston, 'Peripheral Visions: American Mainline Protestants and the Global Cold War', Cold War History, 13, 1 (2013), 109-30; Katharina Kunter, 'Is the East-West Political Bipolarity the Foundation of the Ecumenical Movement? The Cold War as a Meta-Narrative of the World Council of Churches', Occasional Papers on Religion in Eastern Europe, 39, 4 (2019) 28-43; Nadezda Beljakova, Thomas Bremer, and Katharina Kunter, 'Es gibt keinen Gott!' Kirchen und Kommunismus: Eine Konfliktgeschichte ('There Is No God!' Churches and Communism: A Conflictual History) (Basel and Vienna: Herder Freiburg, 2016); Jill K. Gill, 'The National Council of Churches and the Cold War', in Paul Mojzes, ed., North American Churches and the Cold War (Grand Rapids: William B. Eerdmans, 2018), 99-132; Gene Zubovich, 'The Protestant Search for "the Universal Christian Community” between Decolonization and Communism', Religions, 8, 17 (2017), https://doi.org/10.3390/ rel8020017; Miriam Dobson, 'Protestants, Peace and the Apocalypse: The USSR's Religious Cold War, 1947-62', Journal of Contemporary History, 53, 2 (2018), 361-90; Victoria Smolkin-Rothrock, 'The Ticket to the Soviet Soul: Science, Religion, and the Spiritual Crisis of Late Soviet Atheism', The Russian Review, 73 (2014) 171-97.

14 Samuel Moyn, Christian Human Rights (Philadelphia: University of Pennsylvania Press, 2015); Gene Zubovich, 'The Global Gospel: Protestant Internationalism and American Liberalism, 1940-1960', PhD Thesis, University of California, Berkeley, 2015; Pamela Slotte, “Blessed Are the Peacemakers": Christian Internationalism, Ecumenical Voices and the Quest for Human Rights', in Pamela Slotte and Miia Halme-Tuomisaari, eds., Revisiting the Origins of Human Rights (Cambridge: Cambridge University Press, 2015), 293-329. For an excellent collection of recent contributions, see Sarah Shortall and Daniel Steinmetz-Jenkins, eds., Christianity and Human Rights Reconsidered (Cambridge: Cambridge University Press, 2020). 
the Global North to South; as I show in this article, its attempt in the 1970s to work more effectively along the latter axis came at a severe cost with respect to its role along the former. ${ }^{15}$

Drawing on archival research and published source materials, this article brings together these strands of research (both Anglophone and German) to analyse in a single frame the story of the WCC's embrace of religious freedom as a human right, its incorporation of the Russian Orthodox Church, and the ensuing clash, as religious and political dissidence proliferated, between the imperatives of dialogue and denunciation. Whereas previous accounts have been more limited in temporal or thematic scope, restricted in their access to archival materials, or tended to focus heavily - often in partisan fashion - on changes in the WCC's leadership and ideology in the $1970 \mathrm{~s},{ }^{16}$ my explanation considers both institutional and ideological continuities and discontinuities, in conjunction with shifts in the politics of religion in the Soviet Union, human rights, and the Cold War. It thereby shows how the WCC's commitment to ecclesiastical diplomacy combined with a political reorientation towards the Global South to produce a policy that was out of step with the rise of an increasingly powerful movement in support of religious and other dissidents in the Soviet Union.

\section{Christian Fellowship and Religious Freedom across the Iron Curtain, 1948-1961}

The WCC was the most important embodiment of the twentieth-century ecumenical movement. ${ }^{17}$ Its founding assembly, which brought representatives of 147 different churches from forty-four countries together in Amsterdam from 22 August to 4 September 1948, included leading Christian thinkers, clergy, and laypeople, such as John Foster Dulles, Karl Barth, and Martin Niemöller. The predominantly Protestant organisation, composed initially of primarily Western churches (excluding the Roman Catholic Church), promoted Christian unity but also engaged in international affairs, bringing Christian witness to bear on questions such as peace, human rights, and decolonisation. ${ }^{18}$ The WCC, and particularly the body that represented it on the international stage, the Commission of the Churches on International Affairs (CCIA), was one of the earliest actors to embrace the concept of human rights, resulting above all from American ecclesiastical activism. ${ }^{19}$ As the central hub in a sprawling, worldwide network with a constituency of many dozens of millions

15 Justin Reynolds, 'Against the World: International Protestantism and the Ecumenical Movement between Secularization and Politics', PhD Thesis, Columbia University, 2016; Udi Greenberg, 'The Rise of the Global South and the Protestant Peace with Socialism', Contemporary European History, 29 (2020), 202-19; Christian Albers, 'Der ÖRK und die Menschenrechte im Kontext von Kaltem Krieg und Dekolonisierung' ('The WCC and Human Rights in the Context of the Cold War and Decolonisation'), in Katharina Kunter and Annegreth Schilling, eds., Globalisierung der Kirchen: Der Ökumenische Rat der Kirchen und die Entdeckung der Dritten Welt in den 1960er und 1970er Jahren (Globalisation of the Churches: The World Council of Churches and the Discovery of the Third World in the 1960s and 1970s) (Göttingen: Vandenhoeck \& Ruprecht, 2014), 189-215.

16 Works that fall into the former two categories are cited throughout, below; for examples of the third, see Armin Boyens, 'Ökumenischer Rat der Kirchen und Evangelische Kirche in Deutschland zwischen West und Ost' ('The World Council of Churches and the Evangelical Church in Germany Between East and West'), in Gerhard Besier, Armin Boyens, and Gerhard Lindemann, Nationaler Protestantismus und Ökumenische Bewegung: Kirchliches Handeln im Kalten Krieg (1945-1990) (National Protestantism and the Ecumenical Movement: The Actions of the Churches in the Cold War (1945-1990)) (Berlin: Duncker \& Humblot, 1999), 27-322; Hedwig Richter, 'Der Protestantismus und das linksrevolutionäre Pathos: Der Ökumenische Rat der Kirchen in Genf im Ost-West-Konflikt in den 1960er und 1970er Jahren' ('Protestantism and the Pathos of the Revolutionary Left: The World Council of Churches in Geneva and the East-West Conflict During the 1960s and 1970s'), Geschichte und Gesellschaft, 36 (2010), 408-36; Gerhard Besier, '80 Years of the World Council of Churches: Theological, Political and Societal Ambiguities', Kirchliche Zeitgeschichte, 30, 2 (2017), 294-311.

17 For a programmatic statement on this area of research, see Elisabeth Engel, James Kennedy, and Justin Reynolds, 'Editorial the Theory and Practice of Ecumenism: Christian Global Governance and the Search for World Order, 1900-80', Journal of Global History, 13, 2 (2018), 157-64.

18 Antti Laine, Juha Meriläinen, and Matti Peiponen, 'Ecumenical Reconstruction, Advocacy and Action: The World Council in Times of Change, from the 1940s to the early 1970s', Kirchliche Zeitgeschichte, 30, 2 (2017), 327-41.

19 Slotte, "Blessed are the Peacemakers"; Matti Peiponen, Ecumenical Action in World Politics: The Creation of the Commission of the Churches on International Affairs (CCIA), 1945-1949 (Helsinki: Luther-Agricola-Society, 2012); 
of believers, the Geneva-based organisation possessed greater clout than many secular organisations in disseminating ideas about human rights and exerted influence on international institutions, states, civil society, and public debate. As the influence of churches waned in the West over the course of the postwar decades, the WCC's centre of gravity would shift towards the Global South, and its position on human rights changed accordingly, refocusing on issues of social justice. Its trajectory thus provides a microcosm of how ecumenical Protestants shaped as well as contested the postwar evolution of human rights. ${ }^{20}$

The Amsterdam Assembly endorsed the concept of human rights as a key element in the postwar order, building on ongoing discussions about how to limit state power, the unfettered exercise of which had caused such havoc in the preceding decades. ${ }^{21}$ Underlying ecumenical human rights discourse were ideas connected to 'personalism', a heterogeneous school of thought popularised by Christian thinkers such as Jacques Maritain, Emil Brunner, and William Ernest Hocking. The WCC's embrace of human rights thus represented, at a general level, a stand for the figure of the human person, understood as an individual constituted in a dynamic relationship to his community and to God, in rejection of both the atomism of secular liberal individualism on the one hand and the collectivism of fascism, Nazism, and communism on the other. ${ }^{22}$ Concretely, however, the WCC's work for human rights was focused heavily on the issue of religious freedom, on which the Amsterdam Assembly adopted a separate declaration. ${ }^{23}$ This focus derived from its nature as an ecclesiastical body, which meant that it spoke on the subject with authority and legitimacy, but also from the ideological inchoateness of the ecumenical movement: expressing support for human rights was not uncontroversial, given the theological objections more conservative (European) churchmen harboured against it. ${ }^{24}$ It therefore made sense to focus on religious freedom as a theme that united the churches.

The WCC's framing of religious freedom as a human right placed the concept on universal and therefore ostensibly neutral footing, yet it was meant to provide an instrument in Protestantism's struggle against its ideological opponents. Although the 1940s saw strides toward Catholic-Protestant reconciliation - most notably through the rise of Christian Democracy in Europe - continued Catholic hostility to religious pluralism, particularly in countries like Spain and Italy, meant that the WCC's embrace of religious liberty represented a push against what some called the 'totalitarianism' of Roman Catholicism. And though the ecumenical movement included leading critics of empire, including of the role missionaries had played as its handmaidens, religious liberty also played an important role in securing the rights of missionaries - and Christian minorities - in majority Muslim countries, like Indonesia, against potential encroachment by Islam, which was similarly described as 'totalitarian' in nature. Foremost among ecumenists' concerns, however, was the

John Nurser, For All Peoples of All Nations: The Ecumenical Church and Human Rights (Washington, DC: Georgetown University Press, 2005).

20 See also Bastiaan Bouwman, 'From Religious Freedom to Social Justice: The Human Rights Engagement of the Ecumenical Movement from the 1940s to the 1970s', Journal of Global History, 13, 2 (2018), 252-73; Albers, 'Der ÖRK und die Menschenrechte'.

21 W. A. Visser 't Hooft, ed., The First Assembly of the World Council of Churches: The Official Report (London: SCM Press, 1949), 79-80 and 96.

22 For Brunner's articulation of this at the Amsterdam Assembly, see Visser 't Hooft, The First Assembly, 178. See also Moyn, Christian Human Rights; Terence Renaud, 'Human Rights as Radical Anthropology: Protestant Theology and Ecumenism in the Transwar Era', The Historical Journal 60, 2 (2016), 1-26; Gene Zubovich, 'William Ernest Hocking and the Liberal Protestant Origins of Human Rights', in Shortall and Steinmetz-Jenkins, Christianity, 139-57.

23 Visser 't Hooft, ed., The First Assembly, 97-9.

24 See for the views of American, German, and British ecumenists, respectively, Gene Zubovich, 'For Human Rights Abroad, against Jim Crow at Home: The Political Mobilization of American Ecumenical Protestants in the World War II Era', Journal of American History, 105, 2 (2018) 267-90; Brandon Bloch, 'Faith for This World: Protestantism and the Reconstruction of Constitutional Democracy in Germany, 1933-1968', PhD Thesis, Harvard University, 2018, 97; John Carter Wood, This Is Your Hour: Christian Intellectuals in Britain and the Crisis of Europe, 1937-1949 (Manchester: Manchester University Press, 2019), 207. 
threat posed by communism, which emanated above all from the militant secularism of the Soviet Union. $^{25}$

The founding of the WCC coincided with the onset of the Cold War: at the time of the Amsterdam Assembly, the Berlin Blockade was underway, the Sovietisation of Eastern Europe was proceeding, and the Marshall Plan was being implemented. This presented the WCC with the dilemma of how to position itself. As Dianne Kirby has shown, under the chairmanship of the Anglican Bishop George Bell of Chichester, the WCC's Central Committee issued statements critical of 'totalitarian' communism, especially with regard to religious freedom, and in support of the 1950 intervention in Korea under United Nations auspices. ${ }^{26}$ Given the largely Western origin of its leading participants, and the difference in the overall attitude toward religion between the two blocs, the WCC unsurprisingly leaned towards the West. Yet, as Kirby has demonstrated, at the same time, the organisation sought to remain aloof from the intensifying conflict, and it rebuffed efforts by President Truman to enlist it, alongside the Vatican, in a spiritual alliance against communism. ${ }^{27}$ The report of the Amsterdam Assembly's section on 'The Church and the International Disorder' articulated the need for a third way as follows: 'The greatest threat to peace to-day comes from the division of the world into mutually suspicious and antagonistic blocs. This threat is all the greater because national tensions are confused by the clash of economic and political systems. Christianity cannot be equated with any of these. ${ }^{28}$

This stance derived from the WCC's self-fashioning as offering a universal fellowship, transcending worldly political fissures and challenging the forces of 'secularism' wherever these arose. ${ }^{29}$ Only in this way could the WCC unite a politically heterogeneous membership: its participants included Eastern European Christians who sympathised with or expressed support for communism, most prominently the Czech theologian Josef Hromádka, who famously debated Dulles on 'the East-West issue' at the Amsterdam Assembly. ${ }^{30}$ The organisation's General Secretary, the Dutch theologian W.A. Visser 't Hooft (whom journalists nicknamed 'God's diplomat' or 'the pope of the ecumenical movement'), was committed to the inclusion of churches in the Eastern bloc and not to allow Cold War divisions to stand in the way of manifesting the Universal Church. ${ }^{31}$ Moreover, as his biographer, Jurjen Zeilstra, has written, Visser ' $t$ Hooft hoped that by transcending the East-West conflict, the ecumenical movement could offer a way beyond the confrontation. ${ }^{32}$

The Eastern church most important to the WCC was the Russian Orthodox Church, but it rejected the invitation to participate in the Amsterdam Assembly. Seeking to move beyond this initial disappointment, the WCC's leaders continued to make overtures, and its 1954 Evanston Assembly, which was attended by two Eastern Orthodox observers, marked a renewed commitment. Letters and a series of in-person meetings sought to solve theological disagreements, for instance over the nature of the WCC: Visser 't Hooft successfully allayed Orthodox fears that the WCC would serve as a 'super-

25 Udi Greenberg, 'Catholics, Protestants, and the Violent Birth of European Religious Pluralism', The American Historical Review, 124, 2 (2019), 511-38, at 526-32; Lindkvist, Religious Freedom, 67-98; John Stuart, 'Empire, Mission, Ecumenism, and Human Rights: "Religious Liberty" in Egypt, 1919-1956', Church History, 83, 1, (2014), 110-34; Bouwman, 'From Religious Freedom to Social Justice'.

26 See WCC, Minutes and Records of the Central Committee (hereafter MRCC) 1949, 15-6; MRCC 1950, 91-2; Dianne Kirby, 'The Impact of the Cold War on the Formation of the WCC', in Joachim Garstecki, ed., Die Ökumene und der Widerstand gegen Diktaturen: Nationalsozialismus und Kommunismus als Herausforderung an die Kirchen (Stuttgart: W. Kohlhammer, 2007), 135-58.

27 Dianne Kirby, 'From Bridge to Divide: East-West Relations and Christianity during the Second World War and Early Cold War', International History Review, 36, 4 (2014), 739.

28 Visser 't Hooft, The First Assembly, 91.

29 Reynolds, 'Against the World'.

30 Visser 't Hooft, The First Assembly, 38-9.

31 Some Orthodox churches did join early on: at the WCC's founding, 'the Ecumenical Patriarch of Constantinople, the Greek Orthodox Church, Antioch, Alexandria, and Jerusalem joined and became members immediately'. Jurjen A. Zeilstra, Visser 't Hooft, 1900-1985: Living for the Unity of the Church (Amsterdam: Amsterdam University Press, 2020), 365.

32 Zeilstra, Visser 't Hooft, 370. 
church' and adapted the formulation of the organisation's basis to fit Orthodox desiderata, without alienating his existing constituency. ${ }^{33}$ More importantly, perhaps, by the end of the 1950s the Russian Orthodox Church's attitude shifted: it was now not only eager to further expand its international contacts but found itself supported in this by the state, which sought to instrumentalise such ecclesiastical contacts to boost the Soviet Union's international legitimacy and prestige.

On the position of the Russian Orthodox Church vis-à-vis the Soviet state, Visser ' $t$ Hooft wrote in 1959 that while the Orthodox Church 'has not become a syncretistic body such as were the [Nazi-aligned] Deutsche Christen in the National-socialist period in Germany', the Church had come to accept the limits placed on it as a fact of life, for the time being at least. For instance, when asked about evangelisation, churchmen 'would say that the Church itself is the evangelistic fact'. Thus, Visser 't Hooft concluded, 'the Church is a worshipping church, a conserving church and a waiting church, but not an outgoing church'. ${ }^{34}$ This only stoked Visser 't Hooft's eagerness to extend the ecumenical fellowship to the Russian Orthodox Church, which might rekindle a flame in it. From the perspective of the WCC's promotion of religious liberty, however, it meant that only little engagement from the Orthodox Church itself could be expected. Should the WCC then take the lead in criticising the state, or prod the Orthodox Church into stronger opposition? The WCC's answer to this was basically negative: the leaders of the Orthodox Church, as the WCC's (prospective) brethren in the ecumenical fellowship, should be allowed to indicate - insofar as possible - what best served their needs. ${ }^{35}$ Based on this rationale, the WCC's leadership defended the Russian Orthodox Church's entry, and successfully shepherded its application for membership through the WCC's 1961 New Delhi Assembly. ${ }^{36}$

\section{The Rise of Religious Dissidence and Human Rights in the Soviet Union, 1961-1972}

Once the Russian Orthodox Church had joined the WCC, its numerous delegates began participating in WCC conferences and several Orthodox joined the organisation's staff in Geneva. A number of visits and countervisits were organised, notably including a 1964 visit to the WCC by Patriarch Alexi. ${ }^{37}$ Transnational contacts also intensified more generally: in the lead-up to New Delhi, national ecclesiastical organisations had begun undertaking exchange visits to the Soviet Union, which grew more frequent in the ensuing decades. Depending on the delegation in question, these visits could raise questions of religious freedom. For instance, during a 1956 visit by the National Council of the Churches of Christ in the United States, the WCC's main American constituent, religious liberty was discussed relatively frankly. ${ }^{38}$ Yet church leaders adopted a generally cautious attitude, as according to David Foglesong, '[f]rom the late 1950s through the early 1970s, many Protestant leaders in North America felt that it was better to keep silent about the persecution of believers in the USSR. ${ }^{39}$ According to Andrew Preston, this was matched by a low ebb in the promotion of religious liberty as part of American foreign policy, starting in 1963, a year marked by the outbreak of Buddhist protests in Vietnam, which placed the Kennedy administration in an awkward position, and by the

\footnotetext{
33 Zeilstra, Visser 't Hooft, 367-77.

34 Visser 't Hooft, 'Report on the Visit of a World Council of Churches Delegation to the Orthodox Church and Other Churches in the U.S.S.R., December 1959’, 23 Dec. 1959, WCCA CCIA Country Files/Europe/USSR 1965-/Russian Visitation, 3-18 December 1959, 9.

35 See Visser 't Hooft to Bell, 26 Feb. 1951, 2, WCCA CCIA Country Files/Europe/USSR 1948-1965/CCIA USSR 1948-1952; A. de Weymarn, 'On the Church Situation in the U.S.S.R.', 11 Oct. 1961, WCCA CCIA Country Files/Europe/USSR 19481965/USSR 1955-1956, 2.

36 For the statement on religious liberty adopted at this same assembly, see W.A. Visser 't Hooft, ed., The New Delhi Report: The Third Assembly of the World Council of Churches 1961 (London: SCM Press, 1962), 159-61.

37 Zeilstra, Visser 't Hooft, 389.

38 NCCCUSA, 'American Churchmen Visit the Soviet Union', s.d. [1956], WCCA CCIA Country Files/Europe/USSR 19481965/U.S.S.R. (Up to 1956), 10-16.

39 David S. Foglesong, The American Mission and the 'Evil Empire': The Crusade for a 'Free Russia' since 1881 (Cambridge: Cambridge University Press, 2007), 150.
} 
onset of a thaw in Soviet-American relations. This lasted until the mid-1970s, when actors outside the Nixon and Ford administrations, such as the Democratic Senator Henry Jackson, would precipitate a return of religious liberty to foreign policy. ${ }^{40}$

In their encounters with the Orthodox Church, Western ecumenists sought to ascertain the intentions of both the Russian Orthodox hierarchy - which had to avoid offending the party line, in the knowledge of being watched and weighed - and the Soviet state, in order to determine how best to aid the former. In doing so, they bore in mind the control exerted over the church by the state, while nurturing a cautious hope that church-state relations were at least improving compared to the dire history of persecution between the Bolshevik Revolution and the Second World War. Having been formally reestablished under Stalin in 1943, the Russian Orthodox Church was supervised by the state through the Council for Russian Orthodox Church Affairs; a separate Council for the Affairs of Religious Cults oversaw other denominations, before the two were merged into the Council on Religious Affairs (CRA) in 1965. While the WCC interacted with this state body, its more important interlocutor was the Moscow Patriarchate's Department of External Church Relations, founded in 1946. Initially headed by Metropolitan Nikolai of Krutitsy and Kolomna, who was shunted aside for criticising state religious policy, from 1961 to 1972 it was led by Metropolitan Nikodim of Leningrad and Novgorod, a young clergyman who had risen remarkably rapidly through the hierarchy, and whose figure epitomised the compromises the Russian Orthodox Church made in navigating its predicament, while remaining enigmatic to contemporary observers.

Nikodim, who would in 1975 become one of the WCC's six presidents, has remained a controversial and to some extent inscrutable figure, not least owing to his sudden death from a heart attack in 1978, during an audience with Pope John Paul I. Christopher Andrew has written that Nikodim was an 'agent' of the KGB, but the exact meaning of this remains contested; a CRA report from 1974 identified his loyalty to the state as falling into a middle category of those who cooperated but sought to further church interests at the same time. ${ }^{41}$ Nadezda and Elena Beliakova have argued that Nikodim avoided direct conflict with the state because he believed that while complying with the state's demands, he could ultimately force 'those in power to see the use of the existence of the Orthodox Church in sociopolitical life'. ${ }^{42}$ On a more practical level, the church could use its cooperation to seek concessions, and under Brezhnev it sought to leverage 'its historical role as the national church', at a time when Soviet leaders looked to Russian nationalism to shore up the regime's legitimacy. ${ }^{43}$ But Nikodim and other hierarchs' acquiescent attitude towards the state would lead to private and, later, public criticism by Orthodox believers. ${ }^{44}$

Such open dissent was not present from the start. Jane Ellis, who authored the most comprehensive survey to include both Orthodox church-state relations and dissidence, has written that it was only with Khrushchev's renewed antireligious campaign, which started around 1958 and lasted until his downfall in 1964, that Russian Orthodox Church members began to voice opinions contrary to the Moscow Patriarchate's line. ${ }^{45}$ Khrushchev's campaign included atheist propagandising, the undermining of the church's financial base, and, finally, a 'wave of totally unrestrained administrative pressure' that led to the closure of many churches and monasteries. ${ }^{46}$ This prompted Orthodox believers to

40 Andrew Preston, 'The Spirit of Democracy: Religious Liberty and American Anti-Communism during the Cold War', in Joel Isaac and Duncan Bell, eds., Uncertain Empire: American History and the Idea of the Cold War (New York: Oxford University Press, 2012), 158.

41 Christopher Andrew and Vasili Mitrokhin, The Mitrokhin Archive: The KGB in Europe and the West (London: Allen Lane, 1999), 636 and 640-1.

42 Nadezda Beliakova and Elena Beliakova, 'Die "Sowjetisierung” der Russisch Orthodoxen Kirche' ('The "Sovietisation” of the Russian Orthodox Church'), Kirchliche Zeitgeschichte, 30, 1 (2017), 216.

43 Anderson, Religion, State and Politics, 89.

44 It should be noted that even during Khrushchev's antireligious campaign, not all Orthodox Christians acquiesced in the centralisation of the Church: a movement of 'True Orthodox', also known as the 'catacomb church', preferred an underground, illegal existence. This loosely organised network exerted a formative influence on many later religious dissidents.

45 Ellis, The Russian Orthodox Church, 290.

46 Chumachenko, Church and State in Soviet Russia, 193. 
petition church leaders and the state, but given that these were unresponsive, some eventually sought international support. Thus, appeals for outside help began to reach the West, including the WCC, which in some cases responded by contacting Soviet or Russian Orthodox authorities. For example, in 1963, the WCC responded to threats to the Monastery of St. Job at Pochaev, near Lutzk, in the Western Ukraine, where monks were reportedly intimidated and coerced into abandoning their home. ${ }^{47}$ This being said, the WCC's attitude was restrained, and not all appeals were taken up. At its 1964 Executive Committee in Odessa, the first to take place in the Soviet Union, an anonymous appeal by Russian Orthodox Christians was 'ignored' even as the meeting discussed United Nations efforts at drafting a declaration on 'religious intolerance'. ${ }^{48}$ In a letter to Soviet authorities after the meeting, Visser ' $t$ Hooft addressed the issue of antireligious propaganda in general, attempting to find common ground by appealing to common humanity, in a manner emblematic of the WCC's cautious, diplomatic approach. ${ }^{49}$

Orthodox dissent challenging the Moscow Patriarchate's line intensified in 1965, most significantly through a November-December 1965 pair of open letters by Nikolai Eshliman and Gleb Yakunin, both Orthodox priests. The letters - addressed to the Patriarch and to the Chairman of the Presidium of the Supreme Soviet, respectively, but sent to the entire Moscow episcopate - protested the steps taken during Khrushchev's antireligious campaign to strengthen the state's control over the church. In particular, the writers decried a 1961 synodal decree that had established so-called Councils of Twenty to govern parishes, with the effect of extending lay influence over churches. These lay councils were easily subject to state infiltration and pressure, leaving clergy in a vulnerable position. The response to the letters came from the church itself: the Patriarch asked the authors to rescind their criticism, and, when they refused to do so, suspended them from the priesthood. ${ }^{50}$ This highlighted the limits to intra-church dissent, feeding into a long-term shift towards seeking international support and resorting to the language of human rights, as Yakunin's reappearance as a prominent dissident in 1975, discussed below, would symbolise.

As Orthodox dissidence grew, it developed links to the secular intelligentsia that was the source of an emergent dissident movement at the same time, and from which, from 1965 on, a Soviet human rights movement would grow. A milestone in the convergence between Christianity and the intelligentsia came with Aleksandr Solzhenitsyn's 1972 publication of a so-called 'Lenten Letter' to the head of the Russian Orthodox Church, Patriarch Pimen. As Vladislav Zubok has written, Solzhenitsyn was an 'Orthodox believer and a conservative Russian nationalist', but despite the differences in orientation to the mostly liberal, outward-looking intelligentsia this entailed, his work commanded their admiration. ${ }^{51}$ In the letter to Pimen, Solzhenitsyn sharply reproached the Orthodox hierarchy for submitting to the state, particularly in matters such as education, baptism, and the shortage of churches. The right way, Solzhenitsyn claimed, would be for the church to 'sacrifice. Though deprived of all material strength, it is always victorious in sacrifice.' A reply by an Orthodox priest, Father Sergi Zheludkov, illustrated the hierarchy's position: in his view, it should 'try somehow to accept the system and for the present [make] use of those opportunities that are permitted'. ${ }^{52}$ A third position, articulated by the layman and religious dissident Felix Karelin, sided with

\footnotetext{
47 Nolde to H.E. Mr. Luka Y. Kizya, 28 Dec. 1962, WCCA CCIA Country Files/Europe/USSR 1948-1965/73. U.S.S.R. 19601963.

48 Zeilstra, Visser ' $t$ Hooft, 388. On the failure of these efforts, see Steven L.B. Jensen, The Making of International Human Rights: The 1960s, Decolonization, and the Reconstruction of Global Values (Cambridge: Cambridge University Press, 2016), ch. 5 .

49 J. A. Hebly, 'Religious Liberty, the World Council of Churches and the U.S.S.R.', in J. A. Hebly, Michael Bourdeaux, and Eugen Voss, eds., Religious Liberty in the Soviet Union: WCC and USSR: A Post-Nairobi Documentation (West Wickham: Keston College, 1976), 12.

50 Michael Bourdeaux, Religious Ferment in Russia: Protestant Opposition to Soviet Religious Policy (London: Macmillan and St. Martin's Press, 1968), 184-6.

51 Vladislav Zubok, Zhivago's Children: The Last Russian Intelligentsia (Cambridge, MA: Harvard University Press, 2009), 309.

52 Quoted in Ellis, The Russian Orthodox Church, 304-5.
} 
Solzhenitsyn's criticism but drew from this not the conclusion that the church should speak out, but, in Ellis's words, rather that it should refrain 'from action, negating self in order to serve as the instrument of God'. ${ }^{53}$ This debate brought out the fault lines between competing Orthodox views on the proper course of action for the church vis-à-vis the state, which reflected not only its predicament under communism but more deeply rooted theological positions. Ellis suggests that the underlying conflict was 'between those who believed', as Zheludkov did, 'that the church must be preserved as an institution and those who believed', like Solzhenitsyn, 'that the church was above all a metaphysical body'. ${ }^{54}$ Karelin's view, while broadly aligned with Solzhenitsyn, showed itself more sensitive to the need to preserve the church as an institution, but suggested that it should suffer what it must, rather than sully itself in an unequal collaboration with the state.

While the WCC agreed with Solzhenitsyn that there was a pressing need to increase religious freedom in the Soviet Union, its reliance on official contacts predisposed it to side with the church hierarchy's position. On a 1972 visit to the Soviet Union, Visser 't Hooft - now honorary president of the WCC - undertook conversations about Solzhenitsyn with two Orthodox metropolitans, Alexis and Nikodim, and the second-highest official of the CRA, Petr Makartsev, whom he had known since 1959. He showed himself understanding of the position of the Russian Orthodox Church's leaders, saying to Alexis that Solzhenitsyn 'seemed not to understand the real dilemma' confronting them. Yet Visser 't Hooft also saw the letter 'as an opportunity to enter into frank discussion with government officials and Christians of Russia and to ask concrete questions about the real obstacles which the churches in Russia meet in the fulfilling of their mission', leading him to query his interlocutors about religious freedom. Their responses were courteous, but they dismissed Solzhenitsyn's letter and the line of critique it represented, suggesting the limits to how far, as Visser ' $t$ Hooft had put it in conversation with Alexis, the Russian churchmen could 'help us [church leaders in the West], so that we could help them'. ${ }^{55}$

Orthodox representation at the WCC itself also encouraged a cautious attitude on the WCC's part, inviting 'silent diplomacy' rather than public denunciation. The Orthodox representative at the WCC, the respected Archpriest Vitali Borovoi, for example, highlighted the challenges the Russian Orthodox Church faced and was critical of dissidents like Yakunin and Eshliman. Borovoi advised Visser 't Hooft's successor as general secretary, the American Eugene Carson Blake, that the 1965 Eshliman-Yakunin letters had in fact been written by Anatoli Levitin and Karelin, whose character he called into question, and which suggested that Eshliman and Yakunin had been instrumentalised by figures outside the church. Borovoi's advice thus militated against supporting dissident appeals and emphasised the importance of preserving the unity of the Russian Orthodox Church, inviting a cautious approach by the WCC. But as pressure grew on the WCC to act in cases where church leaders were at odds with individual clergy or believers, the organisation's commitment to the Russian Orthodox hierarchy caused it to come under increasing pressure.

\section{Dialogue or Denunciation: The WCC amid the Crosscurrents of the 1970s}

By the early 1970s, religious and political dissidence in the Soviet Union were closely bound up. At the same time, it was also becoming clear, as Ellis has written, that the Moscow Patriarchate 'was not going to change, and exhortations addressed to it dwindled with the passing years'. This did not mean the end of Christian activism, quite the contrary: appeals to the West only intensified. The most important religious dissident group, the Christian Committee for the Defense of Believers' Rights in the USSR,

\footnotetext{
53 Ellis, The Russian Orthodox Church, 306-7. When Solzhenitsyn was expelled from the USSR in 1974, similar exchanges to the one around the Lenten letter erupted. For the WCC's public response in that instance, see Ecumenical Press Service, 'Solzhenitsyn', 15 Feb. 1974, WCCA GS 42.3.125/3.

54 Quoted in Ellis, The Russian Orthodox Church, 304-5.

55 Visser 't Hooft, 'Conversations About the Letter of Solzhenitsyn', Apr. 1972, WCCA GS 42.3.125/3, 2 and 6.
} 
founded by three Russian Orthodox Christians at the end of 1976, one of whom was Yakunin, would by the early 1980s succeed in sending over 1,300 pages of samizdat documents to the West. ${ }^{56}$ This must be understood in light of the explosion of human rights language in international politics around this time, in which Soviet dissidence played a major role as a cause célèbre. Major impulses in this regard were provided by the multilateral forum established by the 1975 Helsinki Final Act (the product of the Conference on Security and Cooperation in Europe; CSCE), the rise of transnational human rights activism symbolised by Amnesty International, and the inclusion of human rights as an element of foreign policy by the Carter administration and other governments. ${ }^{57}$ As a result of this, public pressure on governments to respect human rights became increasingly commonplace, and religious liberty in the Soviet Union stood out as a particularly salient issue.

In this context, Soviet dissidents, perceiving church hierarchs as collaborating with the state, issued strong criticisms of figures such as Nikodim. A telling example is provided by the scientist Valery Chalidze, whose 1973 overview of the dissident movement included a brief section on religion. Chalidze showed empathy for the 'tyranny' the Russian Orthodox Church faced, which meant it struggled simply 'to exist'. He wrote that he understood that 'it is natural that church officials sometimes render unto Caesar excessively', although 'my own ethic is different'. But Chalidze then went on to criticise 'the instances of church hierarchs making common cause with Caesar in persecuting or deceiving believers', as he accused Nikodim of having done in the case of Boris Talantov (a mathematics teacher and friend of Levitin, who in 1969 had been sentenced to two years in a labour camp for his advocacy of religious freedom, where he had died). ${ }^{58}$ Thus, Nikodim figured as an enemy of the dissident movement rather than a friend in fraught circumstances, as the WCC was inclined to see him.

As more and more information became available on religious repression and human rights, and grassroots human rights activism became a major current in Western social movements, the WCC came under pressure to act publicly, too. Small research institutes such as Keston College (established in 1969), based in Oxford, England, Glaube in der 2. Welt (founded in 1972), based near Zürich, Switzerland, and the Inter-Academical Institute for Missiological and Ecumenical Research (established in 1970), in Utrecht, the Netherlands, provided information which implied that action to help Eastern dissidents was imperative. As Mark Hurst has shown in his history of Michael Bourdeaux and his organisation, Keston College, the group's academic credentials were key to its authority, while at the same time it was essentially 'activist' in nature. ${ }^{59}$ In this expertise-based activism, it was in many ways similar to Amnesty International, with which Bourdeaux developed good relations. A major difference, however, was that Keston College focused exclusively on the Soviet Union and Eastern Europe, whereas Amnesty's guiding principle was to devote equal attention to the First, Second, and Third Worlds. Keston College was therefore less independent from international politics and leaned towards the right rather than the left, as illustrated vividly by Margaret Thatcher's embrace of the organisation in 1984, which signalled its willingness to be associated with political anticommunism. Bourdeaux would clash publicly with the WCC in the same year, after which relations with Keston College were 'acrimonious', according to Hurst. ${ }^{60}$ In a 1985 article, Bourdeaux analysed the WCC's record on human rights, concluding squarely that ' $\mathrm{i}] \mathrm{t}$ is only realistic to suggest that the WCC policy towards the Soviet Union has failed'. ${ }^{61}$

\footnotetext{
56 Ellis, The Russian Orthodox Church, 326 and 9.

57 Moyn, The Last Utopia, ch. 4.

58 Valery Chalidze, To Defend These Rights: Human Rights in the Soviet Union, 1st edn, trans. Guy Daniels (London: Collins and Harvell Press, 1975; 1974), 158-64.

59 Mark Hurst, British Human Rights Organisations and Soviet Dissent, 1965-1985 (London and New York: Bloomsbury, 2016), 144.

60 Hurst, British Human Rights Organisations, 141.

61 Michael Bourdeaux, 'The Russian Church, Religious Liberty and the World Council of Churches', Religion in Communist Lands, 13, 1 (1985), 26 and 24.
} 
The rise of European organisations like Keston College dovetailed with the rise of conservative evangelical human rights activism, especially in the United States. When, in the 1940s, American ecumenists framed religious liberty as a human right, conservative evangelicals remained suspicious of the Universal Declaration of Human Rights, for its secularity, its connection to the United Nations, and its association with the liberal Protestantism of the WCC. But by the 1970s, this was rapidly changing: responding to the testimony of imprisonment and torture by the Romanian pastor-in-exile Richard Wumbrand, the writings and expulsion of Solzhenitsyn, and reports by nongovernmental organisations, conservative (as well as some liberal) evangelicals took to criticising Eastern-bloc repression, to which end they drew on the language of human rights. ${ }^{62}$ In so doing they built on and imitated the campaign for Soviet Jews' right to emigrate, which culminated in Congress's adoption of the Jackson-Vanik Amendment (1974), setting back the normalisation of US-Soviet trade relations. Through the 1976 establishment of a congressional Helsinki Commission, anticommunist Christians allied with members of Congress to bring further pressure to bear on the Soviet Union. ${ }^{63}$ This was not the only area in which evangelicals pursued human rights during these years - the more liberal among them critiqued American support for apartheid South Africa or dictatorships in Latin America - but the plight of persecuted Christians under communism was by far the most salient and consequential cause they championed. ${ }^{64}$

Pressure on the WCC to act more publicly would come, too, from a reorientation on the part of the Catholic Church, with the election of Pope John Paul II in 1978. In the early Cold War, Pope Pius XII had positioned the Vatican as emphatically anticommunist, aligning itself with American, and more generally Western, foreign policy. His successors, John XXIII and Paul VI, led a turn toward issues concerning the Third World instead, positioning the church critically in regard to both East and West, for instance in the 1963 encyclical Pacem in Terris. The Second Vatican Council (1962-5) gave Catholic reformers the upper hand, stimulating Catholic-Protestant dialogue and cooperation, and contributing to a momentary opening for Christian-Marxist dialogue, while from the mid-1960s on, the Vatican initiated agreements on church rights with Eastern European governments. ${ }^{65}$ The Vatican's attitude toward Eastern Europe had, in other words, moved in the direction of the ecclesiastical diplomacy of the WCC. Yet John Paul II's ascendancy marked a renewed divergence: while not outright returning to Pius XII's anticommunism, the new pope pushed back against Catholics' embrace of liberation theology and vocally supported Eastern European dissidents, not least in his native Poland, aligning himself on this issue with the Reagan administration. Notwithstanding the pope's criticism of American policies in Latin America, Catholic human rights talk thus shifted markedly towards the Western side in the Cold War. ${ }^{66}$

Meanwhile, during the 1970s and 1980s, the WCC positioned itself as a global voice for human rights. But in contrast to Amnesty International, which sought to claim a similar status, the WCC did not adhere to an apolitical stance and instead oriented itself squarely towards the left. ${ }^{67}$ While Amnesty represented a minimalist form of activism focused on decontextualised individual victims

62 Melani McAlister, The Kingdom of God Has No Borders: A Global History of American Evangelicals (New York: Oxford University Press, 2018), ch. 6.

63 Anna Su, Exporting Freedom: Religious Liberty and American Power (Cambridge, MA: Harvard University Press, 2016), ch. 5. On Soviet Jewish emigration's relation to human rights in the 1970s, see also Nathan Kurz, Jewish Internationalism and Human Rights after the Holocaust (Cambridge: Cambridge University Press, 2020), ch. 6.

64 In addition to McAlister, The Kingdom of God, see Lauren F. Turek, To Bring the Good News to All Nations: Evangelical Influence on Human Rights and U.S. Foreign Relations (Ithaca and London: Cornell University Press, 2020), ch. 4-6.

65 Giuliana Chamedes, A Twentieth-Century Crusade: The Vatican's Battle to Remake Christian Europe (Cambridge, MA: Harvard University Press, 2019), 306. See also Heléna Tóth and Todd H. Weir, 'Religion and Socialism in the Long 1960s: From Antithesis to Dialogue in Eastern and Western Europe', Contemporary European History, 29 (2020), 127-38.

66 Piotr Kosicki, 'The Catholic Church and the Cold War', in Artemy M. Kalinovsky and Craig Daigle, eds., The Routledge Handbook of the Cold War (London and New York: Routledge, 2014), 259-71. I differ from Kosicki in reading human rights as a site of Cold War confrontation rather than dialogue.

67 On the 1960s roots of this development see Greenberg, 'The Rise of the Global South'; cf. Gene Zubovich, 'U.S. Protestants, Globalization, and the International Origins of the Sixties', Diplomatic History, 45, 1 (2021), 28-49. On earlier 
of political repression, such as imprisonment, torture, or execution, the WCC's ambition was to address the systemic 'root causes' of a wide range of injustices, including not only civil and political but also social and economic rights, as well as the collective right to self-determination. This stance, which was worked out over the course of the early 1970s, culminating in a 1974 consultation in the Austrian town of St. Pölten and the WCC's 1975 Nairobi Assembly, was part of a wider reorientation of the WCC towards concerns emanating from the Global South and the Western (religious) New Left. Liberation theology, emerging primarily from Latin America, where both Protestants and Catholics were engaged in a struggle against the rise of military dictatorships such as that of Pinochet in Chile in 1973, led the WCC to reformulate human rights in wide-ranging terms of social justice, inflected by neo-Marxism. Underlying this shift was a change in leadership, whereby many of the Western men who had been with the organisation from its early days were replaced by a more ethnically, geographically, and denominationally diverse group of leaders (diversity in terms of gender was slower in coming), symbolised by the 1972 election of Philip Potter, from the British Caribbean territory of Dominica, as the WCC's first black general secretary. As the internationally representative body of the WCC, the CCIA led the overhaul of the WCC's human rights agenda, which constituted a drastic widening of its scope, whereby religious freedom was no longer the focus it had previously been. More generally, the WCC's Third Worldist focus led to strong criticism of the West, not least through the new flagship Programme to Combat Racism, which drew particular attention to Southern Africa, where apartheid and Portuguese empire endured. ${ }^{68}$

This reorientation invited criticism of the WCC's conduct in relation to the Soviet Union, however, from those who felt that it was insufficiently active in speaking out on religious liberty, especially in support of dissidents. The fact that the WCC was willing to vocally denounce human rights violations in Latin America and elsewhere seemed to critics incongruent with its reluctance to do so in the Soviet Union. Mounting dissidence undercut the WCC's position that protests should be undertaken 'with sensitivity where people are liable to suffer as a result', as in the Soviet case, where, unlike in most of Latin America, church leaders signalled a desire for restraint, lest public denunciations lead to a worsening of church-state relations. ${ }^{69}$ Nowhere was this tension more glaringly on display than at the 1975 Nairobi Assembly, which adopted the WCC's new human rights agenda but was rocked by an appeal from Yakunin and the Orthodox layman Lev Regelson, which Ellis has described as 'probably the most effective religious samizdat document to come out of the Soviet Union'.70 While Potter did not allow the letter into the assembly's formal proceedings, long excerpts were published in the conference periodical Target. The authors criticised the WCC's lack of public protest in the face of religious persecution in the Eastern bloc. The letter called for the WCC to make religious liberty 'the central theme of Christian ecumenism', and in fact proposed that 'the doubts about the spiritual quality of the ecumenical movement may be banished only if confession of the Cross in the original sense of the Gospel - as trials and tribulations for the sake of Christ's Name - become the basis for Christian unity'. ${ }^{71}$ With this call in the background, the assembly's scheduled discussion on the Helsinki Final Act, which had been adopted a few months prior, became highly charged.

roots still, see Justin Reynolds, 'From Christian Anti-Imperialism to Postcolonial Christianity: M.M. Thomas and the Ecumenical Theology of Communism in the 1940s and 1950s', Journal of Global History, 13, 2 (2018), $230-51$.

68 See also Katharina Kunter and Annegreth Schilling, "Der Christ fürchtet den Umbruch nicht”: Der Ökumenische Rat der Kirchen im Spannungsfeld von Dekolonisierung, Entwestlichung und Politisierung' (“'Christ Is Not Afraid of Radical Change”: The World Council of Churches Between Decolonisation, De-Westernisation, and Politicisation'), in Kunter and Schilling, Globalisierung der Kirchen, 21-74; Patrick William Kelly, 'Human Rights and Christian Responsibility: Transnational Christian Activism, Human Rights, and State Violence in Brazil and Chile in the 1970s', in Alexander Wilde, ed., Religious Responses to Violence: Human Rights in Latin America Past and Present (South Bend, IN: University of Notre Dame Press, 2016), 95-122.

69 CCIA, Human Rights and Christian Responsibility: Report of the Consultation St. Pölten, Austria, 21-26 October 1974 (Geneva, 1975), 7.

70 Ellis, The Russian Orthodox Church, 355

71 'Two Russians Appeal for WCC Action on Behalf of Persecuted Christians', Target, 25 Nov. 1975, 4-5, WCCA GS $42.3 .125 / 3$ 
During the assembly, the WCC was, as Katharina Kunter has argued, 'unable to come to a clear position or critical reflection on its own attitude towards the question of religious freedom in the socialist states. ${ }^{72}$ Differences of opinion as to whether to take a more outspoken course of action prevailed, and the assembly's resolution on the Helsinki Final Act contained only toned-down phrases on religious freedom in the Soviet Union. An open hearing on the evening of 8 December 1975, at which the precarious position of the Russian churches was discussed in relative openness, contributed to this outcome, by persuading critics such as the general secretary of the Dutch Reformed Church, Albert van den Heuvel, of the need for 'consultation' and 'fraternal debate' with the Russian Orthodox Church. ${ }^{73}$ But while some initially hailed Nairobi as 'a door opened ${ }^{74}$, religious freedom in relation to the Helsinki Final Act was, according to Kunter, subsequently 'delegated' to the CCIA and then the Conference of European Churches, an ecumenical organisation separate from the WCC and distinct in its pan-European scope, which had always tended away from forthright criticism. ${ }^{75}$ Even in the most high-profile case of the following years, when in 1979-80 Yakunin was arrested and given a tenyear sentence for anti-Soviet agitation, the WCC - under pressure to take a strong stance - limited itself to approaching the Russian Orthodox hierarchy, underlining its policy of refraining from 'entering into public debate regarding such cases', albeit while requesting its concerns be conveyed to the 'highest relevant authorities' (to no avail - Yakunin would only be given amnesty in 1987, under Gorbachev) ${ }^{76}$ The WCC's continuing reliance on the Russian church hierarchy stood in stark contrast to the growing transnational movement that lionised dissidents and denounced Soviet repression.

The WCC's longstanding emphasis on dialogue and 'silent diplomacy' as the most effective policy continued to shape its approach during these years. As Kunter has written, the WCC - or at least a preponderance of its leaders - remained convinced that public denunciations would, generally speaking, do more harm than good. ${ }^{77}$ In notes prepared for a speech by Potter in Philadelphia in 1976, the American CCIA staff member Dwain C. Epps wrote that without denying the problem, 'we must say that infrequently do those in the West who would like to help take the trouble to find out what it is, in fact, which does help' ${ }^{78}$ And in 1980, Epps explained to an American ecumenist that denunciations of communism had only contributed to the hostility of Eastern European states to their countries' churches, whereas the WCC's new policy had contributed to a climate in which state-church relations had improved - he gave the examples of Hungary, Poland, East Germany, and the Soviet Union - and international connections had been strengthened. ${ }^{79}$ In the same year, his colleague Erich Weingärtner wrote to a Dutch ecumenist that the CSCE was 'endangered in part by the fact that the human rights issue is frequently employed as a political weapon rather than sought after as a common goal to be achieved'. As Weingärtner wrote,

it is our conviction that the most urgent task facing us is the overall reduction in tensions, which is the only method that has been proven to be effective in the improvement of the human rights situation in Eastern and Western Europe and in the broadening of possibilities of life and work of our member churches in these countries. ${ }^{80}$

This statement was skewed in implying a level of equivalence between human rights East and West, which resulted from the CCIA's shift leftward. But more importantly, Weingärtner's analysis also

\footnotetext{
72 Katharina Kunter, Die Kirchen im KSZE-Prozeß 1968-1978 (The Churches in the CSCE Process 1968-1978) (Stuttgart: Kohlhammer, 2000), 151.

73 David M. Paton, ed., Breaking Barriers: Nairobi 1975: The Official Report of the Fifth Assembly of the World Council of Churches, Nairobi, 23 November-10 December 1975 (London: SPCK and Wm. B. Eerdmans), 169-174, at 170.

74 David Kelly, 'Nairobi: A Door Opened', Religion in Communist Lands, 4, 1 (1976) 4-17.

75 Kunter, Die Kirchen, 151.

76 Konrad Raiser to Metropolitan Juvenaly, 1 Oct. 1980, WCCA CCIA 428.16.4.50 Country files/Europe/USSR/'ROC’.

77 Kunter, Die Kirchen, 234.

78 Epps to Potter, 15 Apr. 1976, 3, WCCA CCIA 428.15.3.4.

79 Epps to Rev. Grover Hartman, 25 Nov. 1980, WCCA CCIA 428.15.3.4, 3-4.

80 Weingärtner to H.A.M. Fiolet, 24 Mar. 1980, WCCA CCIA 428.16.4.50. Emphasis in original.
} 
highlighted the continuing connection between the WCC's quest to transcend Cold War divisions and its desire to increase religious freedom in the East.

\section{Conclusions}

It would take until the ascendancy of Gorbachev for the Soviet Union to relax restrictions on dissent and religious activity. As the process of reform led to the dissolution of the Soviet Union and the end of communism in Eastern Europe, newfound religious liberty became a potent symbol of the Western victory in the Cold War. Religious dissidents and their international supporters could claim part of the credit, and alongside other dissidents have come to occupy center stage in our understanding of the Cold War's end. ${ }^{81}$ The WCC, having been an only muted supporter of religious dissidents, therefore appeared to have fallen short. ${ }^{82}$ It had pursued an approach oriented not toward denouncing Soviet repression but engaging in dialogue, which derived from its character as an ecclesiastical organisation and its hope that this strategy would ultimately generate change. The WCC's ties with the Russian Orthodox Church were meant to help the Church sustain itself as it negotiated its relationship with the Soviet state. Though gradualist, this project represented a challenge to state-sponsored atheism, which had originally foreseen a withering away of Christianity in favour of communism. ${ }^{83}$

As Christian protests against the leadership of the Russian Orthodox Church gained in force, however, converging with the dissident movement's embrace of human rights from the second half of the 1960s, the WCC's commitment to ecclesiastical relations meant it was increasingly out of step with the times. It responded to a number of public appeals, chiefly through its ecclesiastical channels, and in doing so supported the cause of dissidents, amplifying their critiques of Soviet legislation and their references to human rights. But its institutional nature and personal connections to Russian Orthodox hierarchs meant that the WCC refused to join in the recasting of human rights as a language of public denunciation, even as it embraced this approach in other parts of the world. With respect to the Soviet Union, the WCC thus stood in opposition to the 1970s 'breakthrough' of human rights as a language of grassroots public protest and the revitalisation of religious freedom as a battleground in the religious Cold War. The contrast with new organisations such as Keston College, which harnessed the publication of reliable information for the purposes of an activist agenda aligned with anticommunism, made the WCC seem to critics reticent or aloof at best, and ideologically incoherent or compromised at worst.

These problems were compounded by the organisation's widening of its human rights engagement, beyond religious liberty to issues of social justice, which alienated those with more conservative views on the relation between church and politics. As the success of Amnesty International during these years demonstrated, transcending the Cold War could be a highly popular cause. But Amnesty was committed to a minimalist form of liberalism, in its focus on individual civil and political rights, whereas the WCC came to see this approach as narrow and thus sought to transcend liberalism, too. For a few years, at least, it seemed that this could bear fruit, dovetailing as it did with the 1970s campaign for a New International Economic Order. The WCC's marginalisation by the end of the decade reflected the fate of this wider movement, however, which was shipwrecked on the shoals of concerted opposition (especially from the United States), divisions within the Global South, and tensions between the antistatism of Western activists and the state-centrism of postcolonial actors. ${ }^{84}$

${ }_{81}$ See Snyder, Human Rights Activism; Anderson, Religion, State and Politics, 80-82. At the same time, the impact of human rights activism, and religious dissidence in particular, remains contested, as historians such as Benjamin Nathans have cautioned against assuming too readily that a 'Helsinki effect' brought down communism and ended the Cold War. See Nathans, 'Soviet Dissidents', 38.

82 See Kunter, Die Kirchen, 231.

83 See Victoria Smolkin, A Sacred Space Is Never Empty: A History of Soviet Atheism (Princeton: Princeton University Press, 2018).

84 See Julia Dehm, 'Highlighting Inequalities in the Histories of Human Rights: Contestations over Justice, Needs and Rights in the 1970s', International Legal Theory, 31 (2018), 871-95; Roland Burke, 'Competing for the Last Utopia? The NIEO, Human Rights, and the World Conference for the International Women's Year, Mexico City, June 1975', 
Meanwhile, the WCC's reticence to publicly support Soviet dissidents damaged its credibility as a truly global voice for human rights. The WCC's travails highlight how during the latter stages of the Cold War both depoliticised and anticommunist strands of human rights advocacy overtook social justiceand Third World-oriented activism.

Acknowledgements. I would like to thank the editors at Contemporary European History and the anonymous reviewers for their thoughtful comments. I am also grateful to the organisers of the 2018 LSE-GWU-UCSB Graduate Student Conference on the Cold War, where I presented an earlier version of this manuscript, as well as to Alfons Brüning, Vesselin Dimitrov, Katharina Kunter, Lucian Leustean, Piers Ludlow, Samuel Moyn, Svetozar Rajak, John Stuart, and Vladislav Zubok, for their thoughts and comments as I developed this article (including as a chapter of my doctoral dissertation, on which it builds), and to Dwain Epps for sharing his recollections. Research for this article was supported by the Princeton Institute for International and Regional Studies, the Leibniz Institute of European History, the LSE Marshall Institute, the LSE Department of International History, and the Cluster of Excellence 'Contestations of the Liberal Script' (EXC 2055, Project-ID: 390715649, DFG) at the Freie Universität Berlin.

Humanity, 6, 1 (2015), 47-61; Samuel Moyn, Not Enough: Human Rights in an Unequal World (Cambridge, MA and London: The Belknap Press of Harvard University Press, 2018), 117-18.

Cite this article: Bouwman B (2022). Between Dialogue and Denunciation: The World Council of Churches, Religious Freedom, and Human Rights during the Cold War. Contemporary European History 31, 15-30. https://doi.org/10.1017/ S0960777321000503 